\title{
CALIBRATING ELECTROMAGNETIC SHORT SOIL WATER SENSORS
}

\author{
WILLIBALD LOISKANDL ${ }^{1)}$, GRAEME D. BUCHAN ${ }^{2)}$, WOLFGANG SOKOL ${ }^{1)}$, \\ VILIAM NOVAK ${ }^{3)}$, MARGARITA HIMMELBAUER ${ }^{1)}$
}

${ }^{1)}$ University of Natural Resources and Applied Life Sciences, Institute of Hydraulics and Rural Water Management, Muthgasse 18, A-1190 Vienna, Austria.

${ }^{2}$ Soil \& Physical Sciences Department, Lincoln University, Canterbury, New Zealand.

${ }^{3)}$ Institute of Hydrology, Slovak Academy of Sciences, Račianska 75, 83102 Bratislava, Slovak Republic.

Correspondance: W. Loiskandl, Mailto: loiskandl@mail.boku.ac.at

The use of electromagnetic (EM) soil moisture probes is proliferating rapidly, in two broad domains: in field and laboratory research; and in strongly practical applications such as irrigation scheduling in farms or horticultural enterprises, and hydrological monitoring. Numerous commercial EM probes are available for measurement of volumetric water content $\left(\theta_{v}\right)$, spanning a range of measurement principles, and of probe dimensions and sensing volumes. However probe calibration (i.e. the relationship of actual $\theta_{v}$ to probe electrical output) can shift, often substantially, with variations in parameters such as soil texture, organic matter content, wetness range, electrical conductivity and temperature. Hence a single-valued, manufacturer-supplied calibration function is often inadequate, forcing the user to seek an application-specific calibration. The purpose of this paper is to describe systematic procedures which probe users can use to check or re-determine the calibration of their selected probe(s). Given the wide diversity of operating principles and designs of commercially-available EM probes, we illustrate these procedures with results from our own calibrations of five different short probes (length of 5 to $20 \mathrm{~cm}$ ). Users are strongly recommended to undertake such calibration checks, which provide both a) pre-use experience, and b) more reliable in-use data.

KEY WORDS: Soil Moisture Probes, Electromagnetic Probes, TDR, Calibration.

Willibald Loiskandl, Graeme D. Buchan, Wolfgang Sokol, Viliam Novak, Margarita Himmelbauer: KALIBRÁCIA ELEKTROMAGNETICKÝCH SNÍMAČOV VLHKOSTI PÔDY. J. Hydrol. Hydromech., 58, 2010, 2; 29 lit., 8 obr., 2 tab.

Používanie elektromagnetických (EM) snímačov vlhkosti pôdy sa rýchlo rozširuje tak $\mathrm{v}$ terénnom výskume, ako aj v laboratóriu. Sú používané v praktických aplikáciách ako je riadenie závlah na farmách a záhradách, ako aj v hydrologickom monitoringu. Pre meranie vlhkosti pôdy $\left(\theta_{v}\right)$ sú dostupné početné typy komerčných EM snímačov, založených na viacerých princípoch merania a snímače majú rozdielnu vel'kost' snímaných objemov pôdy. Kalibračné krivky takýchto snímačov (t.j. závislosti medzi reálnou vlhkost’ou pôdy $\theta_{v}$ a elektrickým výstupom snímača) sa môžu posúvat' - niekedy podstatne - a to v závislosti od rozdielnych parametrov pôdy, ako je jej textúra, obsah organických látok, rozsah vlhkostí, elektrická vodivost' a teplota. Z toho vyplýva, že jednoznačná kalibračná krivka, dodávaná výrobcom je často neadekvátna, čo núti užívatel'a snímač kalibrovat' v špecifických podmienkach. Ciel'om tohto príspevku je opísat' procedúry, ktoré môžu byt' použité užívatel'mi pri rekalibrácii vybraných typov snímačov. Berúc do úvahy širokú paletu princípov EM snímačov, ilustrujeme tieto procedúry výsledkami vlastných kalibračných testov na piatich typoch krátkych snímačov (dížka od 5 do $20 \mathrm{~cm}$ ). Užívatel'om odporúčame rekalibráciu komerčných snímačov, ktorými získajú predbežné skúsenosti a spol'ahlivejšie výsledky pri meraní vlhkosti pôdy.

KLUUČCVÉ SLOVÁ: snímače vlhkosti pôdy, elektromagnetické snímače, TDR, kalibrácia.

\section{Introduction}

For many applications of soil water sensors, it is insufficient to use a sensor in the field without pre- vious laboratory tests and a critical evaluation of the manufacturer's calibration. One aspect often overlooked is that the obtained value of volumetric water content $\left(\theta_{v}\right)$ is derived from a surrogate 
measured electromagnetic (EM) parameter. The relationship between $\theta_{v}$ and the parameter is central to the calibration procedure. Most common is the Topp relation between $\theta_{v}$ and relative permittivity $\varepsilon_{\mathrm{r}}$ (Topp et al., 1980), valid for a wide range of applications. However, in general, standard calibrations are good only for the conditions they are derived for (e.g. for a sand) and over a limited water content range.

EM signal propagation is affected by several soil physical properties, especially colloid (clay and organic matter) contents, electrical conductivity, bulk density and temperature (Jacobsen \& Schjonning, 1993; Malicki et al., 1996; O'Connor and Dowding, 1999; Gong et al., 2003; Yuanshi et al., 2003). The authors have personal experiences of being consulted to explain obviously wrong readings (e.g., at one extreme, $\theta_{v}>100 \%$ for a saturated clay soil). Results of other authors also clearly demonstrate the need for adjusting or testing the validity of standard calibrations (e.g. Groves and Rose, 2004; Blanc and Dick, 2003). Thus users should not rely uncritically on manufacturers' or standard calibrations, and also recognise that reading accuracy is determined mainly by the specific field soil conditions, and not only by the signal accuracy of the recording system. When installing sensors, it takes little extra effort to take check soil samples for gravimetric analyses. It is also recommended to take samples over a wide range of soil wetness.

Key criteria for sensor selection include: ease of use; reliability; accuracy; range of application; automatic recording capability; sensing volume; the risk of disturbance errors (e.g. due to installation procedure, or in stony soils); and cost. Accuracy is especially critical, and relies on good calibration. Manufacturer's or standard accuracy specifications often pertain to a specific electronic system, and to measurement under very controlled conditions (e.g. in a sand), but need not be valid for the user's conditions, especially in non-standard applications like in soils high in colloids (clay or organic matter, e.g. Burgess et al., 2006), or saline soils, or in materials like organic waste. This paper presents procedures for calibration of EM short soil moisture probes, and illustrates them with results for five commercial probes.

\section{Calibration methods}

Accurate calibration is complicated by the need to a) reproduce conditions similar to those in the final application, and b) avoid uncontrolled variations in $\theta_{v}$ in the calibration soil sample. To ease and improve calibration, we recommend and describe here an automatic procedure, based on Young et al. (1997) and as applied by Loiskandl et al. (2003). However this method has limitations. The most important constraint is the sensor rod length. Hence we distinguish here between short and long sensors. While there is no exact dividing point, for practical applications short sensors are considered to be $\leq 20 \mathrm{~cm}$, and typically $10 \mathrm{~cm}$ or shorter. This paper focuses on calibration of short sensors.

\section{Calibration of short sensors}

For short sensors, a soil sample in a cylinder containing the probe is placed on a weighing scale. Water is supplied by dynamic upward infiltration by an adjustable pump (Fig. 1). The weight and sensor reading are recorded simultaneously, providing paired values of average $\theta_{v}$ (determined gravimetrically) and sensor reading. The soil sample height and sensor length should be the same to ensure equal averaging. Because this calibration procedure imposes an axial moisture gradient along the sensor, it will strictly succeed only for probes which have a linear relation between the output signal and actual $\theta_{v}$, across the range of $\theta_{v}$ occurring in the sample. A simple test of linearity is to partly submerge the sensor rod in water, e.g. $50 \%$ immersion should give a $\theta_{v}$ of $50 \%$. Fig. 2 shows results for two of the probes described below: a) Hydra-probe: a linear relationship was found over the whole rod length; and b) Theta probe: the relation is not linear, but is nearly linear for the main range of $\varepsilon_{r}$ encountered in practice.

Soil permittivity can be represented using a three-phase concept (Woodhead et al., 2003):

$\varepsilon_{r}=\sum\left(\mathrm{V}_{\mathrm{i}} \varepsilon_{i}^{\alpha}\right)^{1 / \alpha}$,

where phase $i(=s, w, a$ for solids, water, air) has volume fraction $V_{i}$ and permittivity $\varepsilon_{i}$. Hence

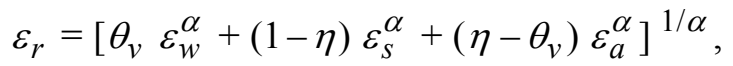

where $\eta$ is porosity, $\theta_{v}$ - volumetric water content (range 0 to 1 ) and $\alpha-$ a shape factor. 


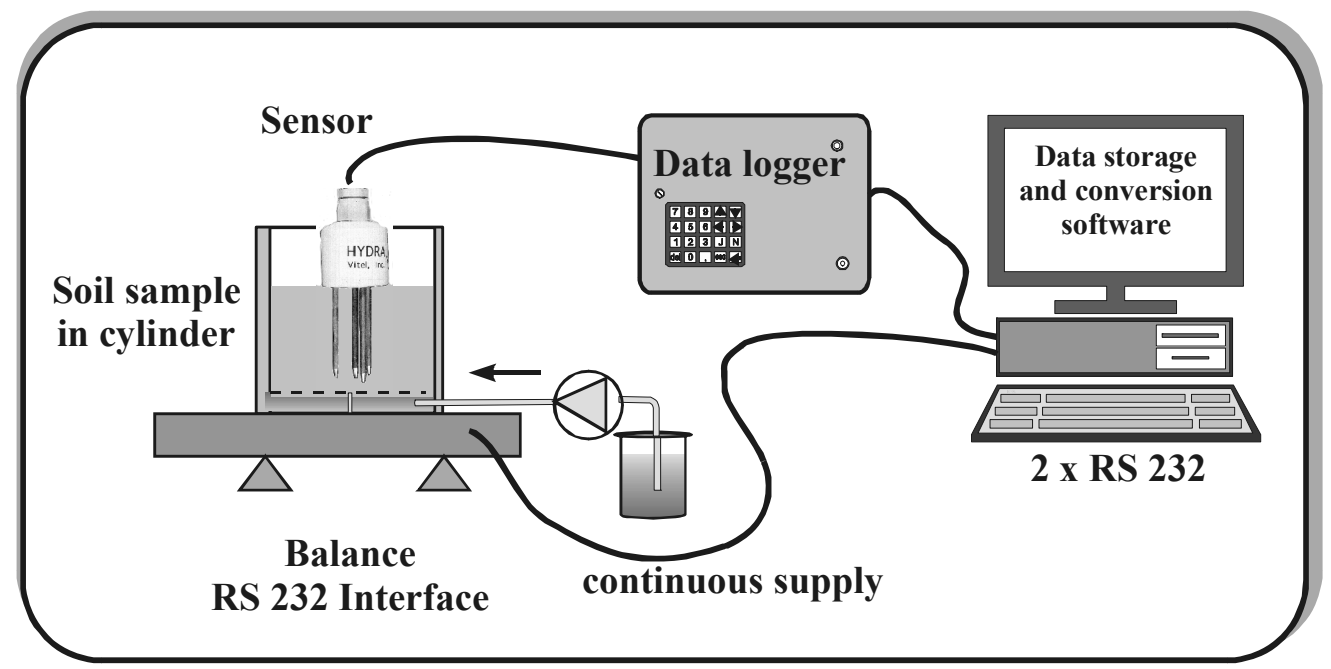

Fig. 1. Set-up for short sensor calibration (example with Hydra-probe). The sample is progressively wetted by upward infiltration of pumped water.

Obr. 1. Zariadenie pre kalibráciu krátkeho snímača (s príkladom snímača Hydra). Vzorka je postupne navlhčovaná infiltráciou tlakovej vody zospodu.

a)

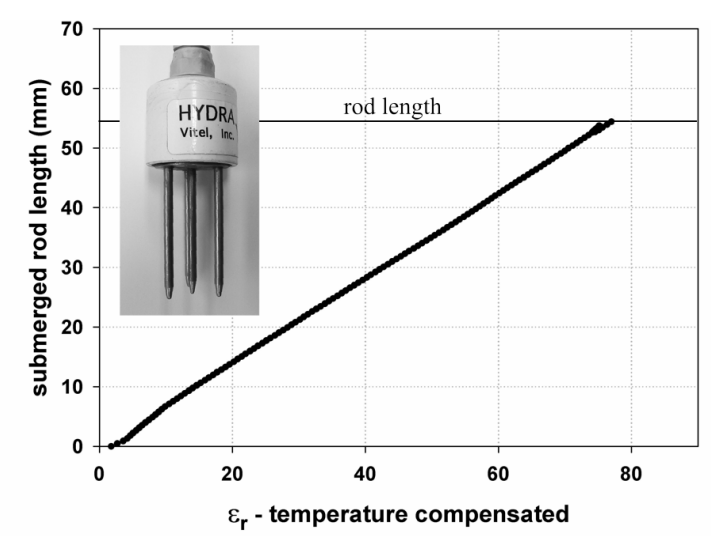

b)

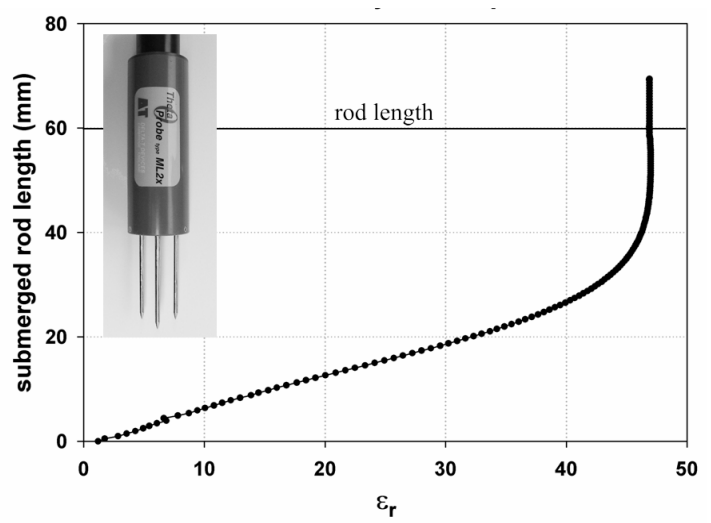

Fig. 2. Test of linearity: relationship between probe length submersed in water and probe output dielectric permittivity, $\varepsilon_{r}$. a) HydraProbe response is linear, while b) Theta-Probe becomes non-linear at high water content.

Obr. 2. Test linearity; vzt’ah medzi dížkou vzorky ponorenej do vody a výstupom $\varepsilon_{r}$ (dielektrická permitivita). a) Snímač Hydra závislost' je lineárna, b) Theta snímač vykazuje pri vyšších vlhkostiach nelineárnu závislost'.

For probe submergence in water, $\eta=1$ and also $\alpha=1$. Hence $\varepsilon_{r}=\left[\begin{array}{lll}\theta_{v} & \varepsilon_{w}+\left(1-\theta_{v}\right) \varepsilon_{a}\end{array}\right]$. With $\varepsilon_{w}$ $=81$ and $\varepsilon_{a}=1$ this gives the linear relation

$$
\varepsilon_{r}=\left(80 \theta_{v}+1\right) \text {. }
$$

\section{Calibration of long sensors}

For long sensors, the same procedure can be applied, but factors limiting its application are as follows. 1. Any sensor leads to different spatial averaging, compared to the gravimetric method. 2. For samples with low hydraulic conductivity (especially clays or compact silts), the time to establish a range of water contents is very long, or even impractical. 3 . The length in combination with the lateral zone of influence leads to a heavy soil sample, requiring a balance weighing this load with high accuracy. Therefore other procedures are recommended, e.g. using a re-packed column with pre-wetted soil. Field calibration is also possible, but takes greater time and effort to cover a sufficient range of $\theta_{v}$ (e.g. Whalley et al., 2004). Further, if the sensor is installed for continuous monitoring, samples must be taken near the probe but outside its sensing volume. 


\section{Overview of the five calibrated types of short sensors}

Since 1990, a wide range of EM soil moisture systems have appeared. For reviews see Topp and Ferre (2002), Evett (2000; 2005), Charlesworth (2000), Robinson et al. (2003). Here we focus on the five short sensors listed in Tab. 1. For the user, most important is a clear definition of what is measured and its relation to soil moisture. Hence Tab. 1 shows the EM principles of the sensors, and Tab. 2 the manufacturers' conversion relations.

\section{Calibration results for the five selected sensors}

For the above sensors, the standard calibrations are analysed here and compared to measurement results. Also summarized are the records or logging procedures used.

\section{TRIME-Probe}

The TRIME TDR system gives only $\theta_{v}$, but is user-friendly. Data transfer is very reliable and, due to the field bus/RS232 system, possible over long distances. User calibration is catered for, and requires special software (IMKO SMCAL Version $2.1,1992)$. Independently measured $\theta_{v}$ are compared with TRIME-Probe values and the polynomial coefficients (Tab. 2) are optimised, then programmed into the probe. Thus each probe can be adjusted to specific conditions, although calibrated sensors are then not easily interchanged. To analyse the standard function, a column filled with sand was used. SM-CAL proved to be a very valuable tool to obtain good results. First, the probe was calibrated (i.e. the polynomial coefficients were optimised) in glass beads. This calibration turned out to be very suitable for the sand. Fig. 3 shows results for 11 different $\theta_{v}$ values, starting at about $45 \%$ and progressing to dry conditions. This calibration was then used in a soil-organic material mix. The larger deviations observed clearly demonstrate the need to obtain a medium-specific calibration (Fig. 3).

$\mathrm{T}$ a b $1 \mathrm{e} 1$. Operating principles and data conversion methods of the five types of sensors.

$\mathrm{T}$ a b u l'k a 1 . Princípy funkcie (measuring concept) a metódy konverzie údajov piatich typov snímačov.

\begin{tabular}{ll}
\hline \multicolumn{1}{c}{ Sensor type/supplier } & \multicolumn{1}{c}{ Measuring concept } \\
\hline TRIME-Probe/ & $\begin{array}{l}\text { Travel time } \tau \text { of a pulse along wave guides (Fundinger et al., 1995). Signal attenuation is } \\
\text { reduced by coating the rods with a non-conductive material. } \tau \text { is converted to } \theta_{v} \text { in an elec- } \\
\text { tronic device using inbuilt coefficients. }\end{array}$ \\
\hline LOM/RS & $\begin{array}{l}\text { As for the TRIME, but uncoated sensor rods. A single-pole-n-throw high frequency multi- } \\
\text { plexer connects sensors to a recording unit. Software converts data and transfers data to the } \\
\text { recording unit. }\end{array}$ \\
EASY TEST & $\begin{array}{l}\text { The Theta-Probe (ML2x) uses a simplified standing wave measurement to determine the } \\
\text { impedance of a 4-rod sensing array (Delta- } T \text { Devices, 1999). The standing wave originates } \\
\text { from a difference of the internal transmission line impedance and the impedance formed by } \\
\text { the array embedded in soil. }\end{array}$ \\
\hline Hydra-Probe/Vitel. Inc. & $\begin{array}{l}\text { Measures the complex dielectric constant, and resolves the capacitive and conductive parts of } \\
\text { electrical response. The capacitive part is most indicative of soil moisture, while the conduc- } \\
\text { tive part reflects mainly soil conductivity (Vitel Inc, 1994). }\end{array}$ \\
\hline $\begin{array}{l}\text { ECH }{ }_{2} \mathrm{O} \text { Probes, Decagon } \\
\text { Devices, Inc. }\end{array}$ & $\begin{array}{l}\text { Measures dielectric permittivity and provides a voltage output easily integrated into data } \\
\text { logging systems (Decagon, 2002; 2008). Sensors with probe lengths of 20 cm (EC-20) and } \\
5 \text { cm (EC-5) are tested. }\end{array}$ \\
\hline
\end{tabular}


a)
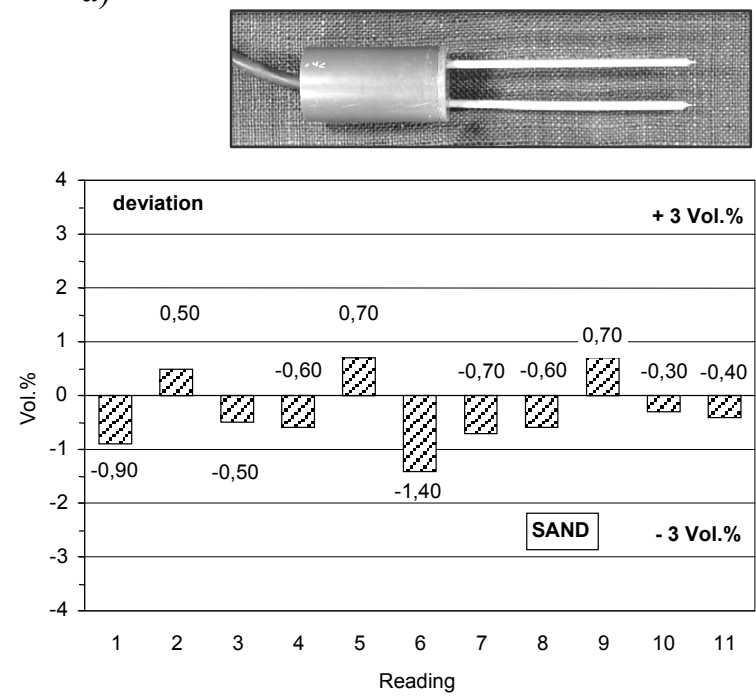

b)

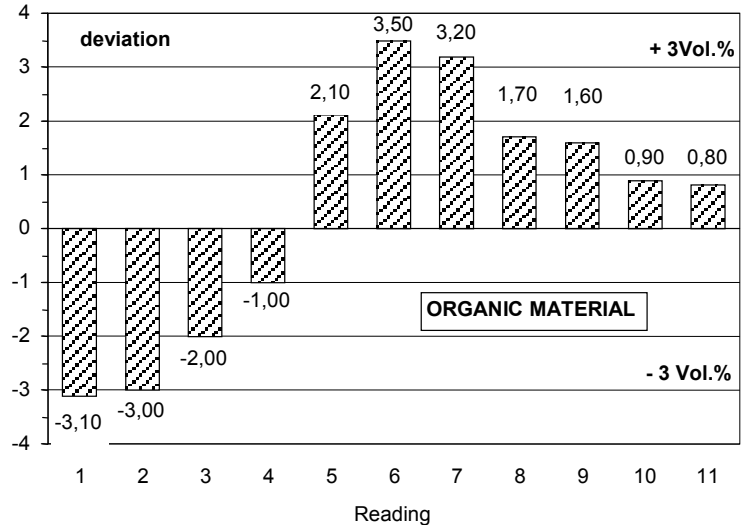

Fig. 3. Deviations $\left(\Delta \theta_{v}\right.$ in \%) of TRIME readings for two medium types: a) sand and b) soil-organic material mix, as obtained by Dreiseitel (1997). Calibration parameters were obtained for glass beads, and gave good results for the sand. For the soil-organic mix, the larger deviations demonstrate the need to obtain a medium-specific calibration.

Obr. 3. Odchýlka $\left(\Delta \theta_{v} \mathrm{v} \%\right)$ snímača TRIME pre dva typy prostredí: a) piesok, b) zmes organického materiálu, podla Dreiseitela (1997). Kalibračné parametre boli získané pre sklené gul'ôčky, s dobrými výsledkami pre piesok. Väčšie odchýlky pre organickú pôdu demonštrujú potrebu získania osobitnej kalibračnej krivky.

\section{Laboratory operated meter for recording soil moisture, LOM/RS}

This TDR equipment was originally designed for controlling long-term laboratory experiments on soil columns, and can be combined with mini tensiometers to provide paired $\theta_{v}$ and suction data for a retention curve (Malicki et al., 1996). The system is controlled by a PC. The supplied software operates the system and performs data conversion $\left(\varepsilon_{r}\right.$ to $\left.\theta_{v}\right)$ using three equations with fixed coefficients (Tab. 2). Nevertheless, the conversion functions gave an almost linear relationship to water content (Fig. 4a)).

To evaluate sensor response in different dry to wet conditions, tests in water and in loam soil were performed. Tests in water: 1 . The uniformity of a set of 20 sensors was tested fully submerged in water; 2. To test for linearity, the sensors were fixed and plates of $5.1 \mathrm{~mm}$ thickness were placed under the cup (inside diameter of $5 \mathrm{~cm}$ ), giving stepwise increase of the submerged depth. The tests were carried out at a constant temperature of $20^{\circ} \mathrm{C}$ and with the probes maintained in a vertical position. Triplicate readings were taken. The results are shown in Fig. 4b). LOM/RS probes gave a very unfavourable response to the linearity test in water, with reasonable results only for submergence $>$ $50 \%$. The most probable cause for this is a secon- dary reflection occurring at the interface between air and water when sensors are submerged less than the resolution length of the system. By contrast, using the $\varepsilon_{r}$ values estimated with the three-phase concept (Eq. (3)) gave results very close to the theoretical $1: 1$ line in Fig. 4b).

In order to the test the sensors before their use in a pot experiment (Himmelbauer and Loiskandl, 2007), measurements were carried out in sand and a loam soil ( $38 \%$ sand, $41 \%$ silt, $21 \%$ clay). The results in loam soil are presented here. Soil samples were packed into $6 \mathrm{~cm}$ high cylinders with inside diameter of $5 \mathrm{~cm}$ to a bulk density of $1.2 \mathrm{~g} \mathrm{~cm}^{-3}$. The measurements were conducted in air-dry soil (hygroscopic water content of $0.02 \mathrm{~m}^{3} \mathrm{~m}^{-3}$ ), at 0.5 saturation $\left(0.27 \mathrm{~m}^{3} \mathrm{~m}^{-3}\right)$, at 0.75 saturation $(0.41$ $\left.\mathrm{m}^{3} \mathrm{~m}^{-3}\right)$, and in a nearly saturated soil $\left(0.51 \mathrm{~m}^{3} \mathrm{~m}^{-3}\right)$. The estimated total porosity was 0.54 , but in practice the maximum $\theta_{v}$ achieved was slightly below that. As before, triplicate TDR measurements were taken. The gravimetric method supplied the reference values. As can be seen on Fig. 5a), the mean offset of the readings (of 20 sensors) from the reference values remained below $5 \%$ for all levels of saturation tested, i.e. $1 \% \pm 1.6$ for the dry soil, $-3.6 \% \pm 2.1$ for the 0.5 saturation, $2.2 \% \pm 1.7$ for the 0.75 saturation and $4 \% \pm 2.8$ for the completely saturated soil. The poorer accuracy at the high water content was probably a result of 
$\mathrm{T}$ a $\mathrm{b} 1 \mathrm{e} 2$. Electrical outputs and manufacturer equations for conversion to $\theta_{v}$, for the five types of sensors.

$\mathrm{T}$ a b u l' k a 2. Elektrický výstup a rovnice pre konverziu na $\theta_{v}$ (kalibračné rovnice) dodané výrobcom, pre pät' typov snímačov.

\begin{tabular}{|c|c|c|}
\hline Sensor type & Output & Manufacturer calibration equations \\
\hline TRIME & $\begin{array}{l}\text { Digital/Fieldbus } \\
\text { IMP232-Micronet }\end{array}$ & Polynomial, order selectable to max order of 5 \\
\hline $\mathrm{LOM} / \mathrm{RS}$ & Digital/RS232 & $\theta_{v}=0$ if $\sqrt{\varepsilon_{r}}<1.48733$ \\
\hline \multirow[t]{2}{*}{ EASY TEST } & (special communication & $\theta_{v}=0.106387 * \sqrt{\varepsilon_{r}}-0.158247$ if $\sqrt{\varepsilon_{r}}<6$ \\
\hline & piviocori) & $\theta_{v}=1-(1-0.106387 * 6-0.158247) *\left(9-\sqrt{\varepsilon_{r}}\right) / 3$ if $\sqrt{\varepsilon_{r}} \geq 6$ \\
\hline \multirow[t]{3}{*}{ Theta-probe } & Voltage $V(0-1 \mathrm{~V})$ & $\theta_{-}[1.1+4.4 V]-a_{0}$ \\
\hline & & $\theta_{0}=\underline{\left[1.07+6.4 V-6.4 V^{2}+4,7 V^{3}\right]-a_{0}}$ \\
\hline & & $a_{1}$ \\
\hline \multirow[t]{4}{*}{ Hydra-probe } & $\begin{array}{l}4 \text { Voltages }(0- \\
5 \mathrm{~V}) / \text { Permittivity }\end{array}$ & $\theta_{v}=C_{0}+C_{1} \varepsilon_{r}+C_{2} \varepsilon_{r}^{2}+C_{3} \varepsilon_{r}^{3}$ \\
\hline & & sand: $C_{0}=-8.63, C_{1}=3.216, C_{2}=-9.54^{*} 10^{-2}, C_{3}=1.579^{*} 10^{-3}$ \\
\hline & & silt: $C_{0}=-13.04, C_{1}=3.819, C_{2}=-9.129^{*} 10^{-2}, C_{3}=7.342^{*} 10^{-4}$ \\
\hline & & clay: $C_{0}=-20.93, C_{1}=6.553, C_{2}=-0.246, C_{3}=3.241^{*} 10^{-2}$ \\
\hline \multirow{3}{*}{$\begin{array}{l}\mathrm{ECH}_{2} \mathrm{O} \text { probes: } \\
E C-20 \\
E C-5\end{array}$} & \multirow{3}{*}{$\begin{array}{l}\text { Voltage } \\
(250-1000 \mathrm{mV})\end{array}$} & $\theta_{v}=b_{1} V-b_{0}$ \\
\hline & & for mineral soils: $b_{1}=0.695, b_{0}=0.29$ \\
\hline & & $b_{1}=1.19, b_{0}=0.401$ \\
\hline
\end{tabular}

$\theta_{v}-$ volumetric water content

$C_{i}$ - polynomial constants

$\varepsilon_{r}-$ real dielectric constant

$\tau$ - square wave period

$V$ - output voltage

$a_{0}, a_{1}, b_{0}, b_{1}-$ calibration coefficients

the vertical probe position and some reflection effects. Nevertheless, the reading deviations from the means are of the order of the accuracy stated in the manual (Fig. 5b)). For horizontal installation, as typical in pot experiments, more favourable conditions can be expected, since at a certain depth a homogenous moisture distribution is easier achieved than in a vertical direction. For exact measurements, a medium-specific calibration is highly recommendable.

\section{Theta probe}

For the Theta probe, the amplitude of a difference voltage $V$ (Tab. 2) gives its relative impedance, hence $\varepsilon_{r}$ and thus a measure of $\theta_{v}$. The data logger needs conversion parameters, either from the manufacturer's calibration or from soil-specific calibration. The calibration method proposed above may be used if linearity of response is assumed for an output signal range $0-1$ Volt, equivalent to $\theta_{v}$ of 0 to $0.5 \mathrm{~m}^{3} \mathrm{~m}^{-3}$. In view of the strong non-linearity of the Theta probe at high $\theta_{v}$ (Fig. 2), instead of submerging in water, it was progressively inserted in a cylinder of saturated coarse $(1 \mathrm{~mm})$ sand. The sensor was fixed vertically and a mobile platform was raised stepwise (Fig. 6a)). This method is discussed by Quinones and Ruelle (2001), who found good agreement (for Campbell Scientific CS615 probes) between progressively inserting the probe, discontinuous mixing of soil with water, and wetting the column from the top with a dripper.

Fig. 6b) shows two test results. The saturated $\theta_{v}$ according to the added water was 0.36 and $0.34 \mathrm{~m}^{3} \mathrm{~m}^{-3}$ for tests 1 and 2 respectively. Corresponding calculated values from the Theta probe were $0.36 \mathrm{~m}^{3} \mathrm{~m}^{-3}$ for both tests. $\sqrt{\varepsilon_{r}}$ was calculated with the third order polynomial (Tab. 2) and for conversion to $\theta_{v}$ the general calibration mineral soil coefficients were used.

If non-linearity of the output signal requires a different calibration, this may be done in the traditional way using homogenously wetted soil samples (Miller and Gaskin, 1999). Paired measurements of gravimetric water content $\theta_{w}$ and output voltage $V$ are needed, and $V$ for dry and wet soils are used to 


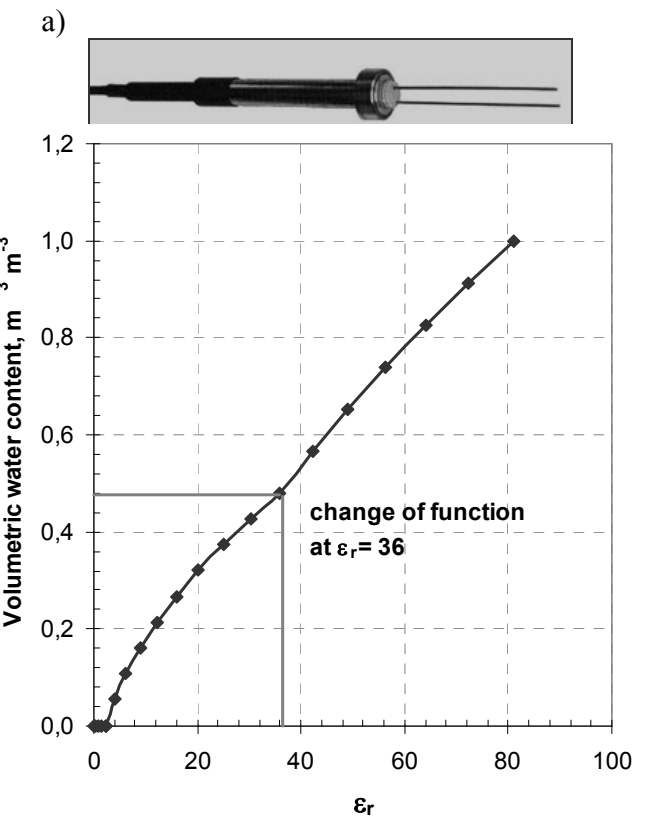

b)

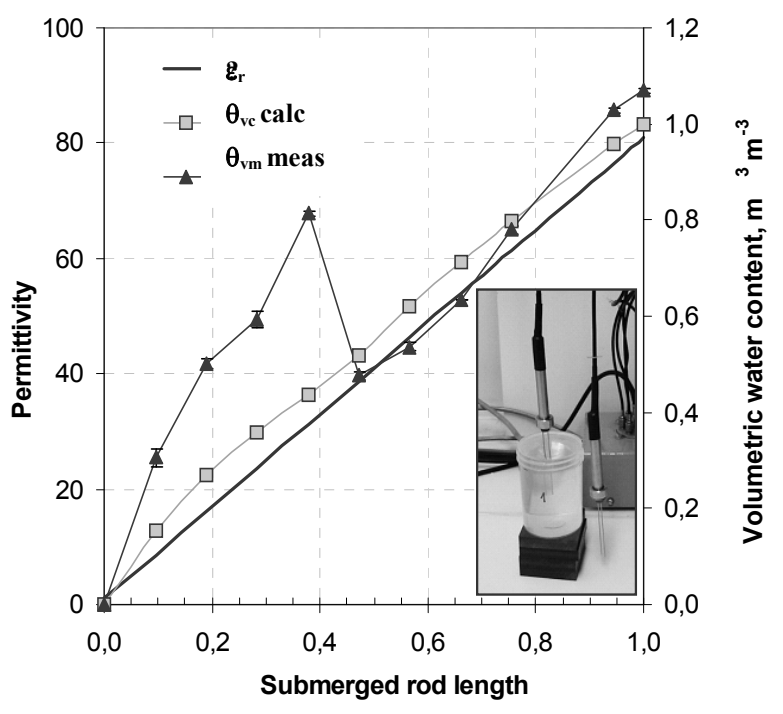

Fig. 4. LOM/RS probes performance: a) Manufacturer's conversion functions (cited in Tab. 2); b) Test of linearity: probe submergence in water; $\varepsilon_{r}$ - line represents the permittivity calculated using Eq. (3), $\theta_{v \text { calc }}$ - the volumetric water content derived from the manufacturer's equations using the calculated $\varepsilon_{r}, \theta_{v \text { meas }}$ - the measured volumetric water content (LOM readings).

Obr. 4. Správanie sa snímačov OM/RS: a) Kalibračná krivka výrobcu (citovaná v tab. 2); b) Test linearity: snímač ponorený vo vode; $\varepsilon_{r}$ - priamka reprezentuje permitivitu vypočítanú pomocou rov. (3), $\theta_{v}$ calc - objemová vlhkost’ získaná pomocou kalibračnej krivky výrobcu s vypočítaným $\varepsilon_{r}, \theta_{v \text { meas }}-$ meraná objemová vlhkost' (LOM).

a)

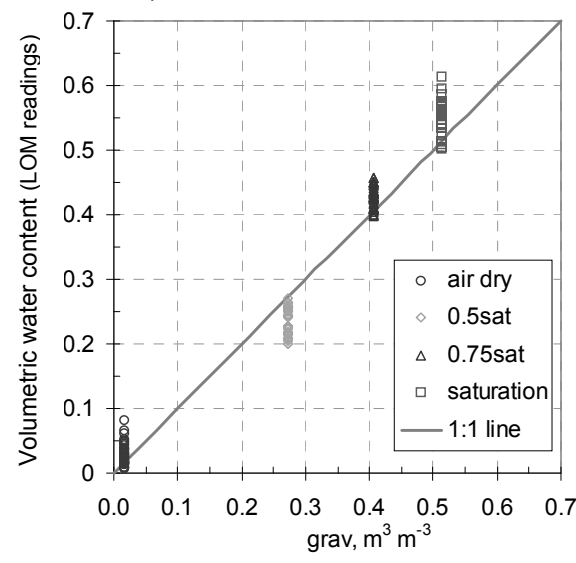

b)

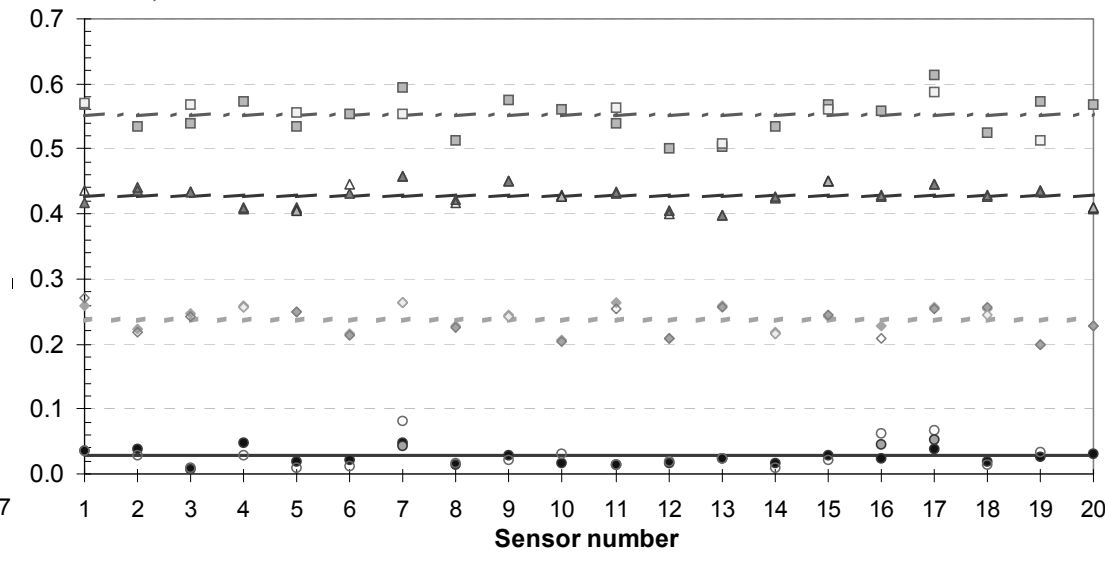

mean, air dry - - - mean, 0.5 sat $\quad-$ mean, 0.75 sat $\quad \ldots$ mean, saturation

Fig. 5. Tests of a set of $20 \mathrm{LOM} / \mathrm{RS}$ probes in a loam soil: a) LOM readings plotted against the gravimetrical estimations of the volumetric water content; b) Scatter of individual probe measurements against the mean value of the four tested water contents: in a nearly saturated soil, at 0.75 saturation, at 0.5 saturation and in an air-dry soil.

Obr. 5. Testy 20 snímačov LOM/RS v hlinitej pôde: a) hodnoty odčítané z LOM-u v závislosti od objemovej vlhkosti pôdy; b) Rozptyl meraní jednotlivých snímačov v závislosti od priemernej hodnoty štyroch vlhkostí pôdy, pri 0.75 nasýtenia, pri 0.5 nasýtenia a pre vzduchosuchú pôdu. 
a)

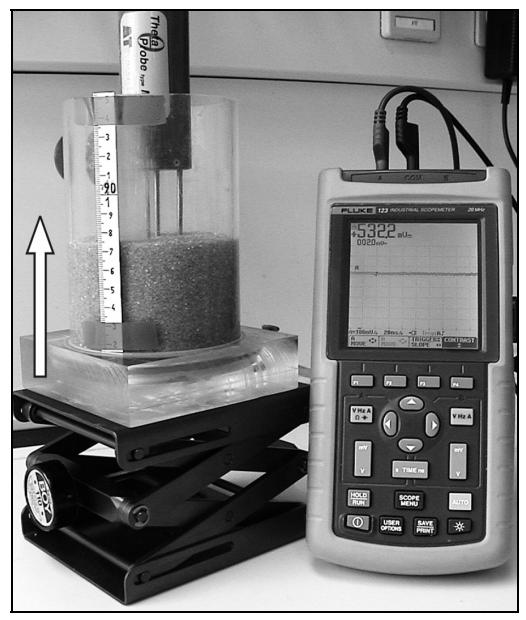

b)

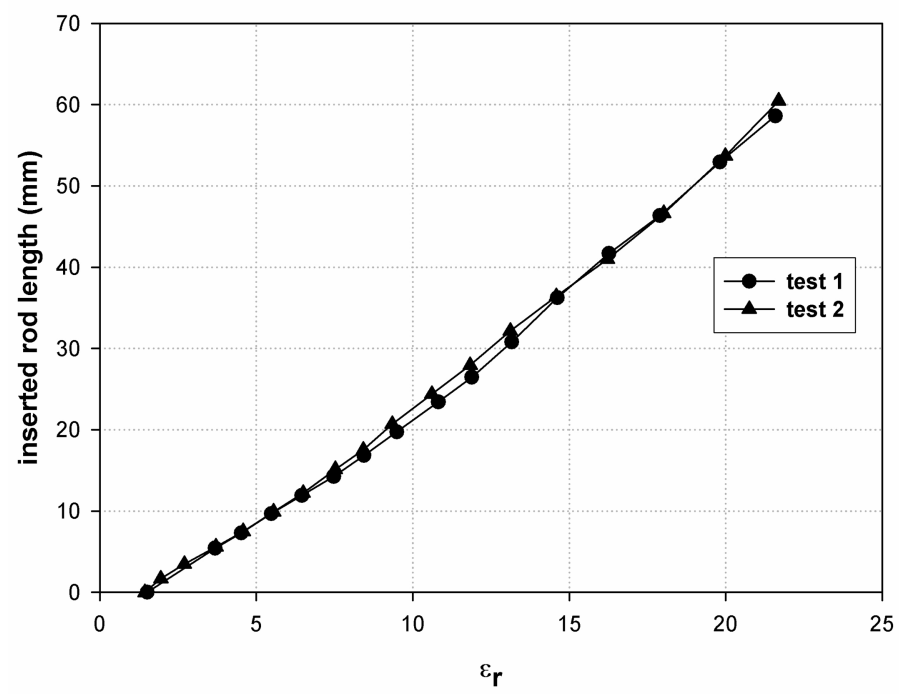

Fig. 6. Theta probe performance: a) Set up for progressive insertion of a sensor in a coarse sand sample; b) Proof of linearity for recommended water content range.

Obr. 6. Snímač Theta; a) zariadenie na ponorenie snímača do hrubozrnného piesku, b) dôkaz linearity pre odporúčaný rozsah vlhkostí.

calculate $\sqrt{\varepsilon_{0}}\left(\equiv a_{0}\right)$ and $\sqrt{\varepsilon_{W}}$ respectively. These then determine, in combination with the corresponding $\theta_{w}$, the coefficient

$a_{1}=\frac{\sqrt{\varepsilon_{W}}-\sqrt{\varepsilon_{0}}}{\theta_{W}}$.

\section{Hydra probe}

The Hydra-probe has four output voltage channels. Permittivity $\varepsilon_{r}$ is calculated from three voltages, similar to a small network analyser for determining the components of impedance. The fourth voltage supplies the temperature, $T$, from a sensor in the probe head. Software transforms the raw voltages to the real and imaginary components of the complex permittivity $\varepsilon$, plus $T, \theta_{v}$ and salinity. Further, temperature corrected values are given. This broad spectrum of soil information is very useful for calibration, but data logging is more laborious. $\theta_{v}$ is calculated via a polynomial (Tab. 2). The supplier's software provides coefficients for three soil types (sand, silt and clay, see Fig. 7a)). A graph of $\varepsilon_{r}$ versus $\theta_{v}$ enables judgement of the range of applicability of the standard values. Fig. 7b) shows an example of our specific calibration results for organic waste material. It is obvious that standard polynomials are only useful for $\theta_{v}<0.5 \mathrm{~m}^{3} \mathrm{~m}^{-3}$. The function for silt shows more realistic values for the higher $\varepsilon_{r}$, though a change from 30 to 50 is accompanied by almost no change in $\theta_{v}$. If the standard coefficients are unsatisfactory, new ones are relatively easily determined with the calibration procedure described above. For soil specific calibration it is important to determine the full saturation, so that no extrapolation is needed over the full measuring range. A polynomial of order $>3$ is generally not justified. For municipal solid waste, a nearly linear relation was found using all data points of five test runs (Fig. 7b)). Using e.g. only one test run would give a different polynomial. MSW is an aggressive medium, which may progressively damage a probe, causing drift in calibration and requiring calibration checks.

\section{$\mathrm{ECH}_{2} \mathrm{O}$ probes}

Most EM sensors perform better in high-sand soils, so that calibration is particularly important for the $\mathrm{ECH}_{2} \mathrm{O}$ probe. According to the factory manual (Decagon, 2002; 2008), the $\mathrm{ECH}_{2} \mathrm{O}$ probe's voltage output is highly proportional to $\theta_{v}$, thus the calibration is a simple linear relation. The probes have low sensitivity to temperature, but output is a function of the supply voltage. For a $2.5 \mathrm{~V}$ excitation, equation constants are provided (Tab. 2). Two types of 
probes were examined: EC-20 and EC-5 with probe lengths of about 20 and $5 \mathrm{~cm}$.

The linearity test for the EC-20 by submerging in water showed a fairly linear probe response, resulting in an appropriate linear regression (Fig. 8a)). The sensor appears to be very suitable for our calibration procedure, so media-specific calibration is easily performed. From the tests in a sand column (grain size $0.2-0.63 \mathrm{~mm}$ ) with a controlled $2.5 \mathrm{~V}$ supply, use of the manufacturer's calibration substantially underestimated the actual water content (Fig. 8a)). The User's Manual (Campbell, 2005) does state that the standard calibration is not accurate for soils with high sand or salt content. However the large difference established (see Fig. 8a)) between the slope of our calibration curve $\left(b_{1}=\right.$ $\left.=2.054, b_{0}=0.834, \mathrm{R}^{2}=0.988\right)$ and the manufacturer's curve $\left(b_{1}=0.695, b_{0}=0.29\right)$ is a clear example supporting our general argument of the need for user specific calibration.

EC-5 probe has a different two-prong design than EC-20. The EC-5 measurement principle is the same as for EC-20, but the higher measurement frequency allows measurements of water content up to $100 \%$ (Decagon, 2008). Therefore, the accuracy is higher than for the EC-20 and at least $0.03 \mathrm{~m}^{3} \mathrm{~m}^{-3}$ for almost all soil types with electrical conductivity (salinity) up to $8 \mathrm{dS} \mathrm{m}^{-1}$. The linearity test in water, however, showed a rather non-linear probe response for the whole range measured, but only at lower water contents (Fig. 8b)). The second test in glass bead columns (Dragonit 25, grain size $0.45 \mathrm{~mm}$ ) was performed in three replications. The samples were prepared in a similar way as for the $\mathrm{LOM} / \mathrm{RS}$ tests. The results also show a non-linear response relative to the reference water content, approximating the shape of the curve in the submerging test (Fig. 8b)). By contrast the manufacturer's equation between water content and voltage output is linear. Thus the calibration procedure using glass beads may not be the most appropriate in the case of the EC-5 probe, possibly because the large pores would result in a system with a 'capillary front' between saturated material below and unsaturated material above. a)

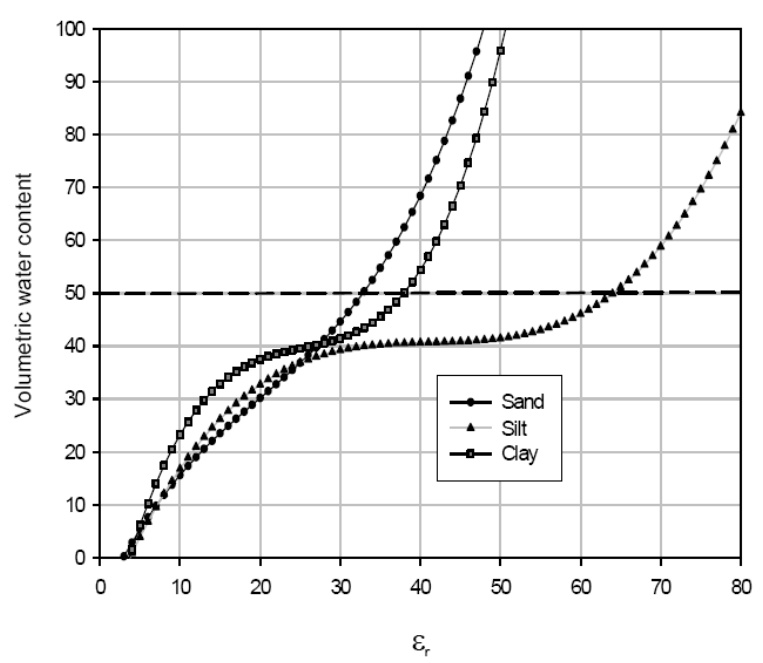

b)

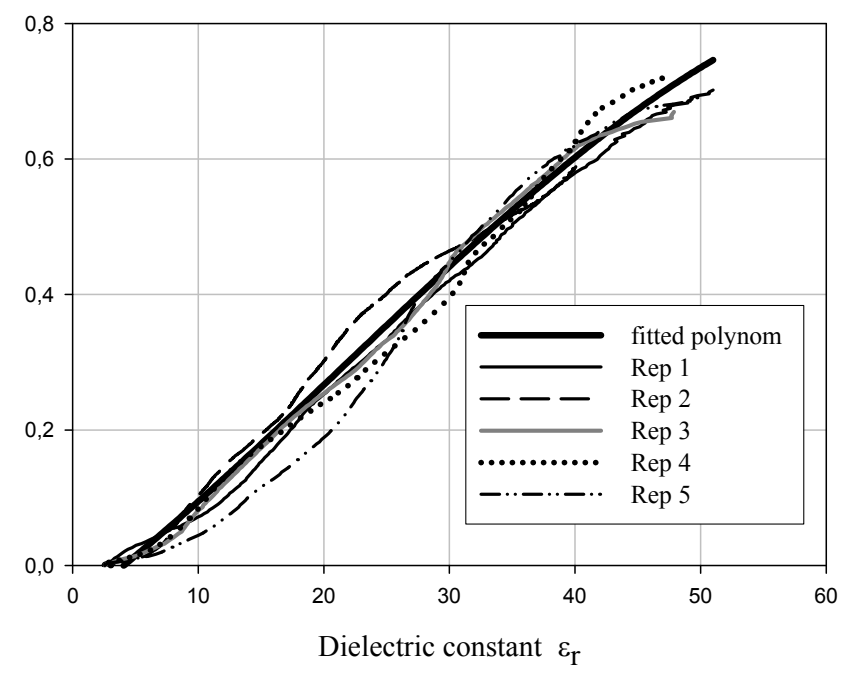

Fig. 7. Hydra probe sensors: a) The manufacturer-supplied relationships of $\varepsilon_{r}$ versus $\theta_{v}$ [\%] for sand, silt and clay; the coefficients for the polynomials are cited in Tab. 2; b) Calibration for organic material from a municipal solid waste site. The polynomial was fitted to data averaged over five replicate samples ( $\theta_{v}$ expressed as a fraction).

Obr. 7. Snímače Hydra; a) výrobcom dodaná závislost’ medzi $\varepsilon_{r}$ a $\theta_{v}[\%]$ pre piesok, prach a hlinu; koeficienty polynómov sú v tab. 2, b) kalibrácia pre organický materiál z verejnej skládky odpadov. Charakteristiky polynómu boli spriemerované z piatich opakovaní ( $\theta_{v}$ je vyjadrené v častiach z vlhkosti vodou nasýtenej pôdy). 
a)
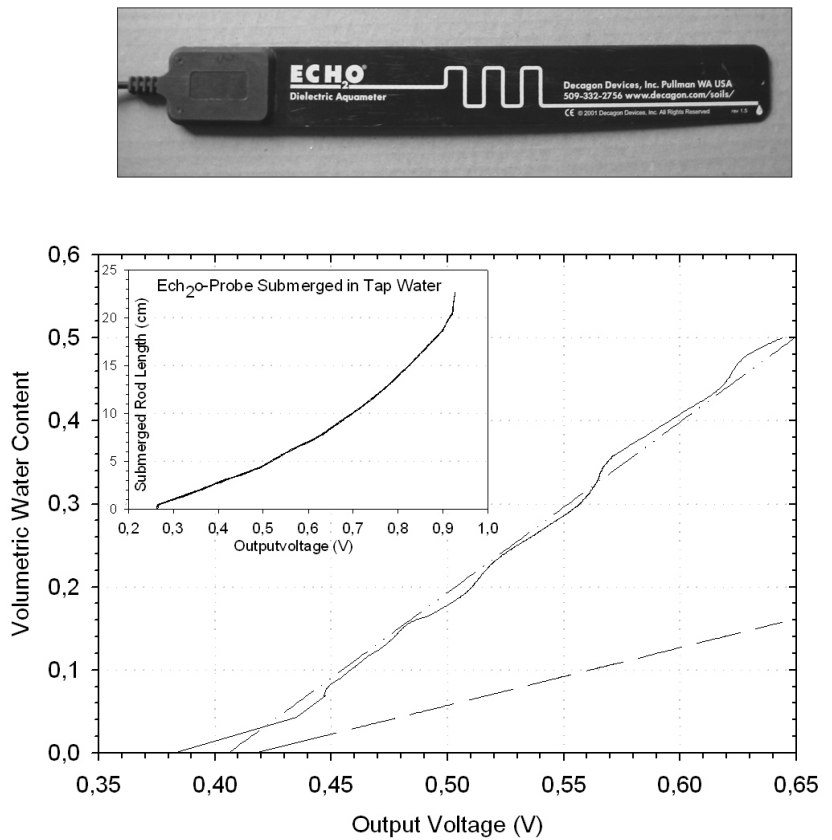

Output Voltage (V)

$$
\begin{aligned}
& \text { measured from water added } \\
& \text { calculated by } \mathrm{ECHO} \text {-function } \\
& \text { (from the manual) } \\
& \text { linear regression } \\
& \text { for measured values }
\end{aligned}
$$

b)
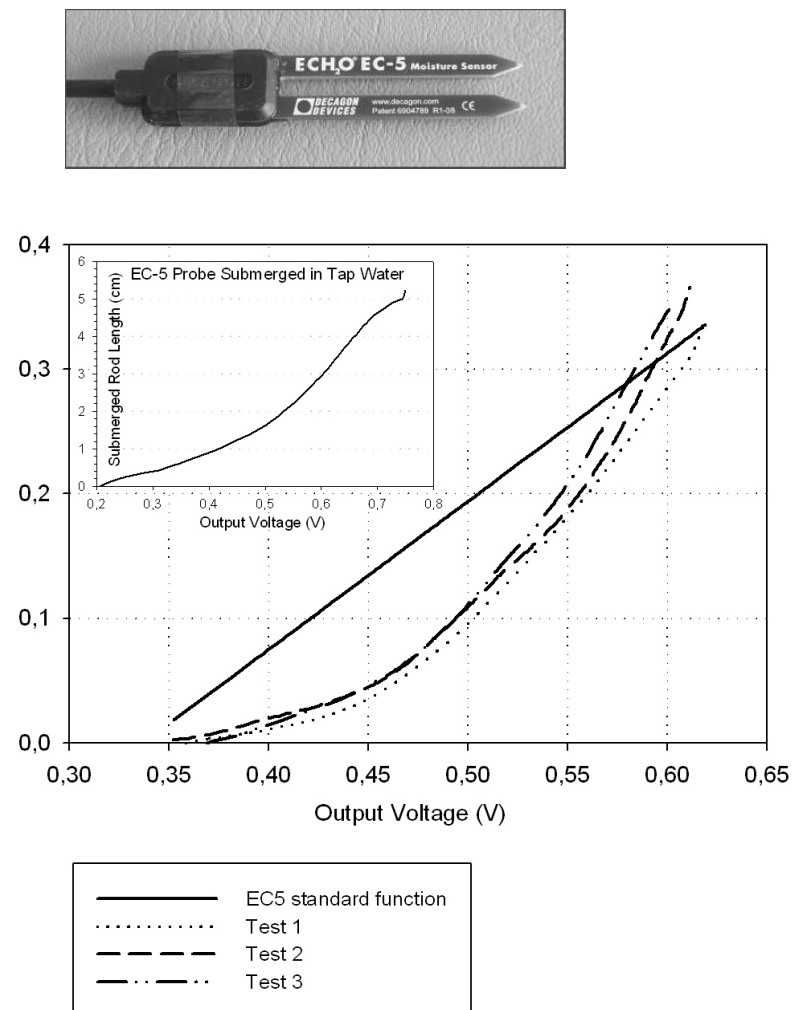

Fig. 8. $\mathrm{ECH}_{2} \mathrm{O}$ probe calibrations for: a) EC-20 probe submergence in water (test of linearity), and in sand; b) EC-5 probe submergence test in water and triplicate measurements in glass beads.

Obr. 8. Kalibrácia snímača $\mathrm{ECH}_{2} \mathrm{O}$ pre: a) EC-20 ponorenú vo vode (test linearity) a v piesku; b) pre EC-5 ponorený vo vode a meranie v sklených gul'ôčkach s trojnásobným opakovaním.

\section{Conclusions}

Measuring water content of composite media such as soils, composts or wastes presents a challenge for many applications. EM probe users should be aware that, for a given volumetric water content, probe output can vary, often strongly, with properties such as texture, organic matter content, electrical conductivity and temperature; and hence that a single manufacturer-supplied calibration may be unreliable, or may only have been derived for a limited range of wetness. Hence users should have transparent, easily implemented calibration procedures. We have presented above simple, easily performed lab calibration procedures which provide good insight into system performance, and have illustrated them for five short-length probes.

Soil-specific lab tests are strongly recommended for both equipment familiarisation, and for testing sensor applicability for a specific task. Field calibration is sometimes essential.
Each EM sensor has its own optimum range of application, the limits of which have to be carefully assessed. Plotting the signal-to- $\theta_{v}$ conversion function is an easy method to identify the sensitivity and the best range of a sensor's application.

\section{List of symbols}

$$
\begin{array}{ll}
a_{0}, a_{1}, b_{0}, b_{1} & - \text { calibration coefficients, } \\
C_{i} & \text { - polynomial constants, } \\
i & \text { - subscript denoting phase }(i=s, w, a \text { for solids, } \\
& \text { water, air), } \\
\text { TDR } & \text { - Time-Domain Reflectometry, } \\
V_{\mathrm{i}} & \text { - volume fraction of phase (inclusion) } \mathrm{i}, \\
V & \text { - output voltage, } \\
\alpha & \text { - shape factor, } \\
\varepsilon_{r} & - \text { relative dielectric permittivity (real part), } \\
\varepsilon_{i} & - \text { relative permittivity of phase } i(i=a, w, s \text { for } \\
& \text { air, water, solids, respectively), } \\
\eta & - \text { porosity, } \\
\theta_{v}, \theta_{w} & - \text { volumetric, gravimetric water content, } \\
\tau & \text { - pulse or square wave period. }
\end{array}
$$




\section{REFERENCES}

BLANC L., DICK J.M., 2003: Errors in repeated measurements of soil water content in pots using a ThetaProbe. Soil Use and Management, 19, 87-88.

BURGESS P.J., REINHARD, B.R., PASTUREL P., 2006: Compatible measurements of volumetric soil water content using a neutron probe and Diviner 2000 after field calibration. Soil Use and Management, 22, 401-404.

CAMPBELL C.S., 2005: Response of $\mathrm{ECH}_{2} \mathrm{O}$ Soil Moisture Probe to Variation in Water Content, Soil Type, and Solution Electrical Conductivity. DECAGON Application Note.

CHARLESWORTH P., 2000: Soil Water Monitoring. CSIRO Irrigation Insights Number 1, Land \& Water Australia, Canberra.

DECAGON DEVICES, Inc., 2002: $\mathrm{ECH}_{2} \mathrm{O}$ Dielectric Aquameter, User's Manual, Version 1.4. Pullman (USA).

DECAGON DEVICES, Inc., 2008: EC-20, EC-10, EC-5 Soil Moisture Sensors, User's Manual, Version 8, Pullman (USA).

DELTA T DEVICES, 1999: ThetaProbe Soil Moisture Sensor Type ML2x User Manual, Vers. ML2x-Um-1.21, Cambridge (UK).

DREISEITEL M., 1997: Bodenwassergehaltsmessung mittels Time Domain Reflectometry. [Diplomarbeit thesis.] Institute für Hydraulik und Landeskulturelle Wasserwirtschaft, Universität für Bodenkultur, Wien.

EVETT S.R., 2000: Some Aspects of Time Domain Reflectometry (TDR), Neutron Scattering, and Capacitance Methods of Soil Water Content Measurement. Pp. 5-49 In: Comparison of soil water measurement using the neutron scattering, time domain reflectometry and capacitance methods. International Atomic Energy Agency, Vienna, Austria, IAEATECDOC-1137.

EVETT S.R., TOLK J.A. HOWELL T.A., 2005: Time Domain Reflectometry Laboratory Calibration in Travel Time, Bulk Electrical Conductivity, and Effective Frequency. Vadose Zone Journal, 4, 1020-1029.

FUNDINGER R., KÖHLER K., STACHEDER M., 1995 Messung der Material- und Bodenfeuchte mit der TRIMEMethode, Ettlingen (D), IMKO GmbH.

GONG Y.S, CAO Q.H., SUN Z.J., 2003: The effects of soil bulk density, clay content and temperature on soil water content measurement using time-domain reflectometry. Hydrological Processes, 17, 2601-2614.

GROVES S.J., ROSE S.C., 2004: Calibration equations for Diviner 2000 capacitance measurements of volumetric soil water content of six soils. Soil Use and Management, 20, 96-97.

HIMMELBAUER M.L., LOISKANDL W., 2007: Measuring soil water content in soil-root media. $15^{\text {th }}$ International Poster Day: Transport of Water, Chemicals and Energy in the Soil-Plant-Atmosphere System, 15 Nov. 2007, Bratislava, Slovakia, p. 133-141 (CD). Slovak Academy of Sciences, ISBN 978-80-89139-13-2.

IMKO GmbH, 1992: Benutzerhandbuch SMCAL Version 2.1 Kalibrierprogramm für Module der Serie SM, Ettlingen (D).

JACOBSEN O.H., SCHJONNING P., 1993: A laboratory calibration of time domain reflectometry for soil water measurement including effects of bulk density and texture. Journal of Hydrology, 151, 147-157.

LOISKANDL W., STANGL R., SOKOL W., 2003: Comparison of Calibration Methods for Electromagnetic Soil Water Sensors. Proceedings of ISEMA, $5^{\text {th }}$ International Confer- ence on Interaction of Electromagnetic Waves with Water and Moist Substances. March 23-28, 2003, p. 234-241. Rotorua, New Zealand.

MALICKI M.A., PLAGGE R., ROTH C.H., 1996: Improving the calibration of dielectric TDR soil moisture determination taking into account the solid soil. European Journal of Soil Science, 47, 357-366.

MILLER J.D., GASKIN G.J., 1999: ThetaProbe ML2x - Principles of operation and application. Macaulay Land Use Research Institute Technical Note ( $2^{\text {nd }}$ ed).

O'CONNOR K.M., DOWDING C.H., 1999. GeoMeasurements by Pulsing TDR Cables and Probes. Boca Raton (Florida), CRC Press.

ROBINSON D.A., JONES S.B., WRAITH J.M., OR D., FRIEDMAN S.P., 2003: A review of advances in dielectric and electrical conductivity in soils using time domain reflectometry. Vadose Zone Journal, 2, 444-475.

QUINONES H., RUELLE P., 2001: Operative calibration methodology of a TDR sensor for soil moisture monitoring under irrigated crops. Subsurface Sensing Technology and Applications, 2, 31-45.

TOPP G.C., FERRE P.A., 2002: Water content. pp. 417-421. In: J.H. Dane and G.C. Topp (eds.): Methods of Soil Analysis, Part 4. SSSA Book Ser. 5. SSSA, Madison, WI.

TOPP G.C., DAVIS J.L., ANNAN A.P., 1980: Electromagnetic Determination of Soil Water Content: Measurement in Coaxial Transmission Lines. Water Resources Research, 16 , 574-582.

VITEL Inc., 1994: Hydra Soil Moisture Probe User's Manual, Version 1.2

WHALLEY W.R., COPE R.E, NICHOLL C.J., WHITMORE A.P., 2004: In-field calibration of a dielectric soil moisture meter designed for use in an access tube. Soil Use and Management, 20, 203-206.

WOODHEAD I.M., BUCHAN G.D., CHRISTIE J.H., IRIE K., 2003: A general dielectric model for time domain reflectometry. Biosystems Engineering, 86, 207-216.

YOUNG M.H., FLEMMING J.B., WIERENGA P.J., WARRICK A.W., 1997: Rapid Laboratory Calibration of Time Domain Reflectometry Using Upward Infiltration. Soil Sci. Soc. Am J., 61, 707-712.

YUANSHI G., QIAOHONG C., ZONGJIA S., 2003: The effects of soil bulk density, clay content and temperature on soil water content measurement using time-domain reflectometry. Hydrological Processes, 17, 3601-3614.

Received 19 November 2009 Accepted 10 March 2010

\section{KALIBRÁCIA ELEKTROMAGNETICKÝCH SNÍMAČOV VLHKOSTI PÔDY}

Willibald Loiskandl, Graeme D. Buchan,

Wolfgang Sokol, Viliam Novak,

Margarita Himmelbauer

Meranie vlhkosti zložených prostredí ako napr. pôd, kompostov alebo odpadov, kladie zvýšené nároky na túto činnost'; používatelia EM snímačov si musia dat' pozor na riziká spojené s meraním vlhkosti, pretože výsledky merania sa môžu výrazne menit' $\mathrm{v}$ závislosti od vlastností meraného prostredia ako je jeho textúra, obsah 
organických látok, rozsah vlhkostí, elektrická vodivost' a teplota. Z toho vyplýva, že jednoznačná kalibračná krivka, dodávaná výrobcom je často neadekvátna, alebo môže byt' urobená len pre úzky rozsah vlhkostí. Preto by užívatelia mali mat' $\mathrm{k}$ dispozícii jednoduché, l’ahko implementovatel'né kalibračné procedúry. Príspevok obsahuje jednoduché, v laboratóriu l'ahko implementovatel'né procedúry, ktoré umožňujú pohl'ad do správania sa meracieho systému a sú ilustrované meraním na piatich typoch krátkych snímačov.

Odporúčame špecifické, laboratórne procedúry pre vniknutie do špecifík meracieho systému a pre otestovanie možností aplikácie zariadenia pre špecifickú úlohu. $\mathrm{V}$ niektorých prípadoch je nevyhnutná kalibrácia $\mathrm{v}$ teréne.

Každý EM senzor má špecifický rozsah aplikácie, ktorej hranice musia byt' určené. Závislost' medzi elek- trickým signálom a $\theta_{v}$ je najlepší spôsob identifikácie citlivosti merania a najvhodnejšieho rozsahu aplikácie.

Zoznam symbolov

$a_{0}, a_{1}, b_{0}, b_{1}$ - kalibračné koeficienty,

$C_{i} \quad-$ konštanty polynómu,

$i \quad-$ index označujúci príslušnú fázu $(i=s, w, a$ pre pevnú fázu, vodu, vzduch),

$V_{i} \quad-$ relatívny objem fázy $i$,

$V \quad-$ výstupné napätie,

$\alpha \quad-$ tvarový faktor,

$\varepsilon_{r} \quad-$ relatívna dielektrická permitivita (reálna čast'),

$\varepsilon_{i} \quad-$ relatívna dielektrická permitivita fázy $i(i=a$, $w, s$ pre vzduch, vodu a pevnú fázu),

$\eta \quad-$ pórovitost,

$\theta_{v}, \theta_{w} \quad-$ objemová a hmotnostná vlhkost',

$\tau-$ pulz 